Яценко Ю. В., аспірант *

Інститут тваринництва НААНУ

\title{
ОКРЕМІ ФІЗИКО-МЕХАНІЧНІ ВЛАСТИВОСТІ КОМБІКОРМІВ ТА ЇХ ВИХІДНИХ ІНГРЕДІЕНТІВ
}

\section{Рецензент - доктор сільськогосподарських наук І. С. Вакуленко}

\begin{abstract}
Наведено результати визначення окремих фізикомеханічних властивостей комбікормів та їх вихідних інтредієнтів, зокрема щзільності абсолютно сухої речовини пшениці, кукурудзи, ячменю, сої, макухи, шроту рапсового, висівок, коефіцієнта внутрішнього тертя та кута природного ухилу. Досліди показують, шзо значення абсолютно сухої речовини (зокрема для різних сортів пшениці) зна-

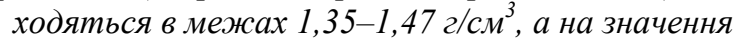
коефіиієнта внутрішнього тертя комбікормів $i$ кута природного ухилу впливає модуль їх помелу. При величині модуля помелу комбікорму 2,3 мм значення коефіцієнта внутрішнього тертя - 0,51, а кута природного ухилу - 42 ; при величині модуля помелу комбікорму 1,76 мм, відповідно, $0,67 \mathrm{ma}_{4} 3^{\circ}$.
\end{abstract}

Ключові слова: інгредіснти комбікормів, фізико-механічні властивості, абсолютно суха речовина.

Постановка проблеми. Відновлення виробництва продукції, зокрема й свинарства, в умовах ринку повинно базуватися на якісно новому технологічному і технічному рівнях, який забезпечує більш повну реалізацію генетичного потенціалу тварин, раціонального використання основних фондів, зменшення виробничих витрат, кормів, робочого часу, енергоресурсів, одержання високоякісних, екологічно чистих, конкурентноспроможних продуктів. Для забезпечення збільшення виробництва продукції тваринництва, поліпшення іiі якості необхідно забезпечити якісну годівлю тварин. Одним із напрямів вирішення даного питання $є$ покращання асортименту та якості комбікормів, які виробляються передусім в умовах господарства.

Аналіз основних досліджень і публікацій, у яких започатковано розв'язання проблеми. Діюча в Україні нормативна документація: «Правила організації і ведення технологічного процесу виробництва комбікормової продукції» [3], «Відомчі норми технологічного проектування ВНТП-АПК-11.07». Комбікормові підприєм- ства» [2] відсутні аналітичні розрахунки технологічних ліній виробництва комбікормів. У доступній нам літературі $\epsilon$ приклади розрахунку технологічних ліній виробництва комбікормів [4], в якій представлено аналітичний розрахунок технологічних ліній з урахуванням нативних показників фізико-механічних властивостей інгредієнтів комбікормів. Нами обгрунтований розрахунок технологічних ліній виробництва комбікормів з урахуванням абсолютно сухої речовини та щільності абсолютно сухої речовини інгредієнтів комбікормів [5]. Однак у літературі відсутній показник щільності абсолютно сухої речовини інгредієнтів комбікормів.

Мета досліджень. Визначення показників фізико-механічних властивостей інгредієнтів комбікормів, зокрема показника щільності абсолютно сухої речовини.

Матеріали та методи досліджень. Для визначення окремих фізико-механічних властивостей вихідних інгредієнтів комбікормів у різних районах Полтавської області провели відбір проб пшениці різних сортів, як озимих, так і ярових, кукурудзи та ячменю. Використовували макуху, шрот рапсовий, висівки.

Для визначення щільності абсолютно сухої речовини (а.c.p.) з відібраних у різних районах Полтавщини і зразків вихідних інгредієнтів комбікормів відбирали проби 3 наступною їх сушкою за температури $105{ }^{\circ} \mathrm{C}$. Далі у підготовлений пікнометр засипали досліджуваний зразок вихідного інгредієнта комбікорму та доливали до мітки пікнометра керосин.

Щільність абсолютно сухої речовини визначалася за рівнянням:

$$
\begin{aligned}
& \rho_{\text {a.c.p. }}=\frac{\mathrm{m}_{\text {а.с.p. }}}{\mathrm{V}_{\text {a.c.p. }}} \\
& \text { де: } \rho_{\text {a.c.p. }}-\text { щільність абсолютно сухої речовини; } \\
& \mathrm{m}_{\text {а.с.p. }}-\text { маса абсолютно сухої речовини; }
\end{aligned}
$$

* Керівник-доктор сільськогосподарських наук В. І. Піскун 


$$
\mathrm{m}_{\text {a.c.p. }}=\mathrm{m}_{1}-m_{2}
$$

де: $\mathrm{m}_{1}$ - маса пікнометра 3 матеріалом, що досліджується;

$\mathrm{m}_{2}$ - маса пікнометра;

$\mathrm{V}_{\text {a.c.p. }}$ - об'єм абсолютно сухої речовини;

$\mathrm{V}_{\text {a.c.p. }}=\mathrm{V}_{1}-V_{2}$;

де: $\mathrm{V}_{1}$ - початковий об'єм керосину в мірному циліндрі;

$V_{2}-$ об'єм керосину, влитого в пікнометр із мірного циліндра.

Вміст вологи $\mathrm{W}_{\text {в }}$ у вихідних інгредієнтах комбікормів у відсотках визначають згідно 3 ГОСТ 13496.3 за формулою [6]:

$$
W_{B}=\frac{m_{1}^{\prime}-m_{2}^{\prime}}{m_{1}^{\prime}} \cdot 100,
$$

де: $m^{\prime}{ }_{1}$ - маса наважки до висушування, г;

$m^{\prime}{ }_{2}$ - маса наважки після висушування, г.

Масу 1000 зерен $\left(m_{\phi}\right)$ або абсолютну масу зерна в грамах за фактичної вологості зерна розраховують за формулою [6]:

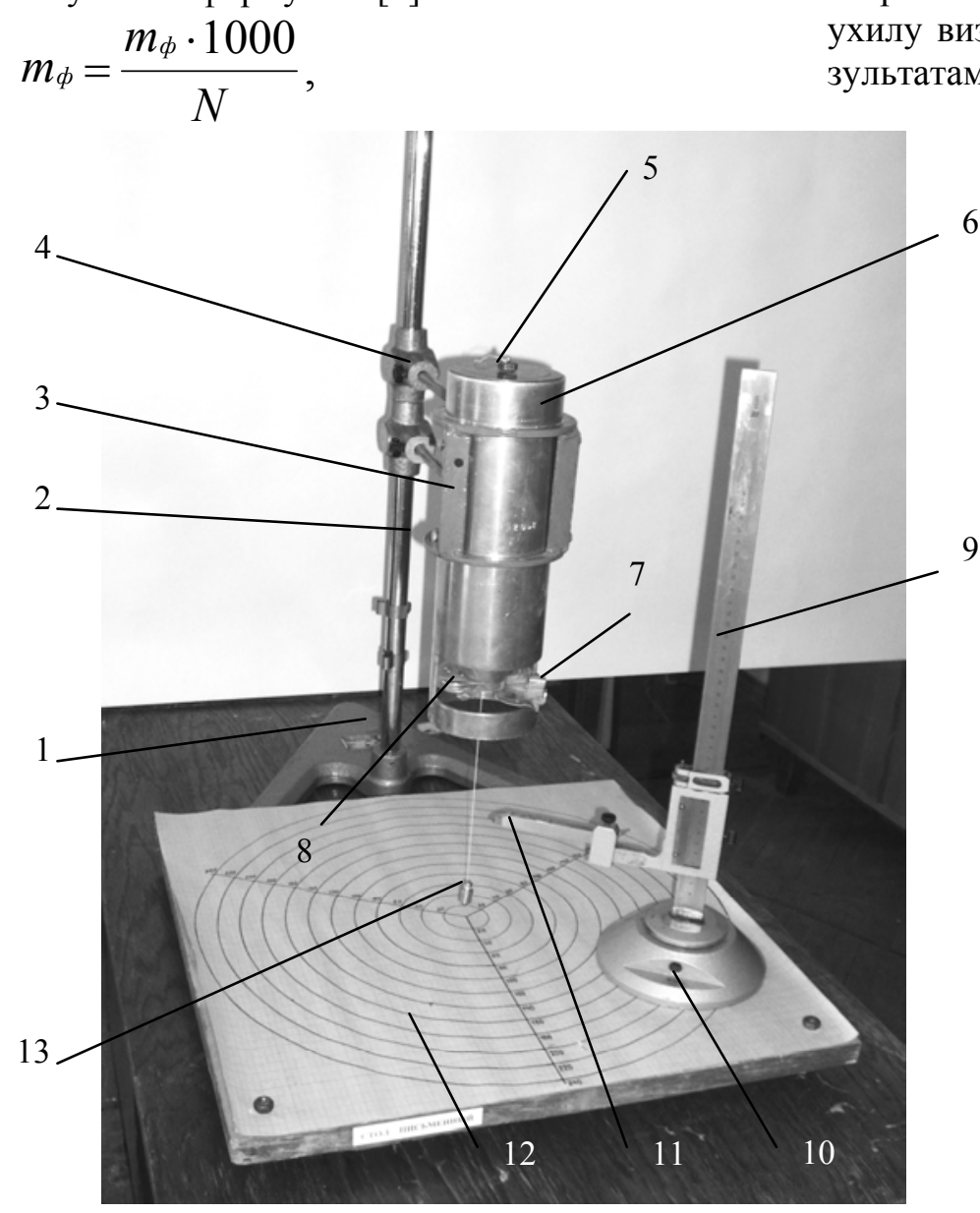

де: $m_{\phi}$ - маса цілих зерен, г;

$\mathrm{N}$ - кількість цілих зерен у масі, шт.

Кут природного ухилу визначали методом висипання із циліндра 3 воронкою на удосконаленому нами приладі, зображеному на рисунку [1].

Прилад складається з таких основних вузлів: основи (1), стойка (2), циліндра (6) з воронкою, кришки циліндра 3 вузлом кріплення виска (5), штангенрейсмуса (10), регулюємої площини (12).

Перед початком досліджень регулюєму площину установлювали по рівню в горизонтальній площині. На циліндр (6) із воронкою установлювали кришку циліндра 3 вузлом кріплення виска (5). Висок (13) установлювали по центру розмітки, яка нанесена на площину (12). Після цього знімали кришку (5) з виском (13) закривали заслінку (7) циліндра (6) з воронкою, в циліндр засипали досліджуваний матеріал. Відкривали заслінку (7). При висипанні з воронки на площину сипучий матеріал, який досліджують, утворює конус. Кут між утворюючою і діаметром основи конуса і $є$ кутом природного ухилу. Знімали показники діаметру основи конуса по шкалі, нанесеній на площині (12), а висоту конуса визначали за допомогою штангенрейсмуса. Повторність досліду десятикратна. Кут природного ухилу визначали через значення тангенсу за результатами замірів (рис. 1).

\section{Рис. 1. Прилад для визначення кута природного ухилу:}

1 - основа;

2 - стойка;

3 - вузол кріплення циліндра;

94 -вузол для регулювання кріплення циліндра;

5 - кришка ициліндра з вузлом кріплення виска;

6 - ииліндр з воронкою;

7 - заслінка;

8 - фіксатор заслінки;

9 - шкала штангенрейсмуса;

10 - штангенрейсмус;

11 - вимірювальна пластина;

12 - регульована площина;

$13-$ висок. 


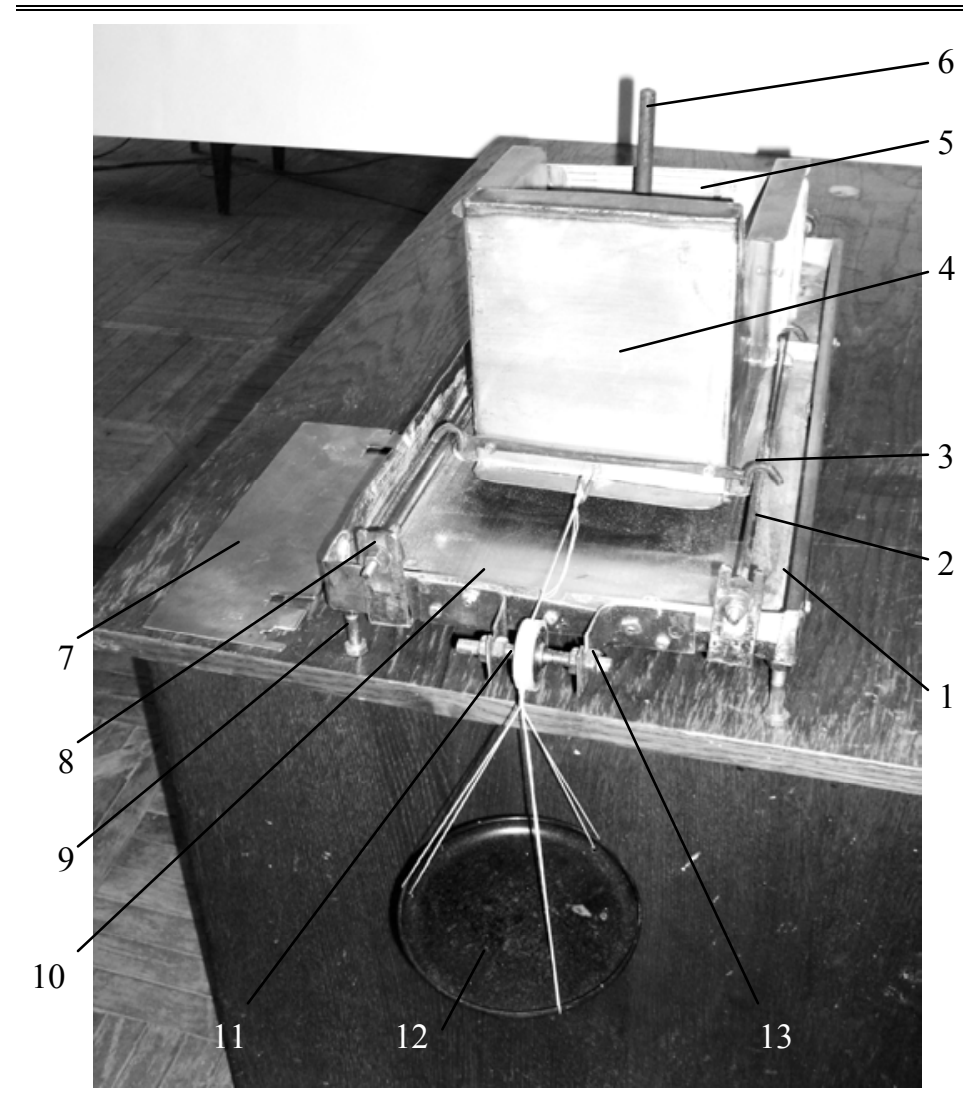

\section{Рис. 2. Установка для визначення коефіцієнтів тертя:}

1 -лоток;

2 - направляючі;

3-опори;

4 - ящик;

5 - икала висоти сипкого

досліджуваного матеріалу;

6 - направляюча з пластиною для

регулювання навантаження на досліджуваний сипкий матеріал;

7 - пластина для установлення висоти та вирівнювання сипкого матеріалу в лотку;

8 - вузол регулювання

направляючих;

9 - опора для регулювання

установки лотка;

10 - нитка;

11 - блок;

12 - тарілка для гирь;

13 - вузол регулювання блока.

Визначення коефіцієнта внутрішнього тертя проводили на удосконаленій нами установці, зображеній на рис. 2 [1].

Установка для визначення коефіцієнтів тертя складається 3 таких основних вузлів: лотка (1) 3 направляючими, ящика (4), пластини для регулювання навантаження на досліджуваний сипкий матеріал 3 направляючою (6), блока (11), тарілки для гирь (12).

Метод визначення $\operatorname{tq}_{\phi}$ та $f_{M}$ полягає в знаходженні граничних напружень стискання $\sigma$ та $\tau$ зсуву.

Спочатку визначаємо опір руху пустого ящика (4) по направляючих (2) за масою гирь, встановлених на тарілку (12), при якому ящик (4) буде виведений зі стану спокою. Потім насипаємо досліджуваний сипкий матеріал у лоток (1) до рівня, що визначається пластиною (7), й вирівнюємо його поверхню.

Установивши ящик у вихідне положення, в нього шаром насипаємо досліджуваний сипкий матеріал, зверху установлюємо пластину 3 направляючою (6) з визначеною масою. Після цього (12) ставимо гирі до тих пір, поки ящик не почне повільно переміщатися. Горизонтальна сила, прикладена в площину руху (площина зіткнення сипкого матеріалу в лотку (1) та ящика (4), долаючи силу тертя, що з'являється в тій же площині від маси сипкого матеріалу висотою $\mathrm{h}$ в ящику та маси $\sum \mathrm{G}$ пластини з направляючою (6). Висоту $\mathrm{h}$ визначаємо за шкалою (5) сипкого матеріалу, який досліджується.

Нормальна напруга стискування в площині ковзання (в кг $\left./ \mathrm{M}^{2}\right)$ рівна:

$$
\sigma=\frac{\sum G}{\Omega}+h_{\gamma}
$$

де: $G$ - маса вантажних пластин, кг;

$\Omega$ - площа перерізу ящика, см$^{2}$;

$h$ - висота шару сипкого матеріалу в ящику між пластинами із площиною ковзання, м;

$\gamma$ - насипна (об'ємна маса) сипучого матеріалу, який досліджують, кг/м³ (визначають за кількістю сипкого матеріалу в даному об'ємі ящика).

Граничну горизонтальну дотичну напругу

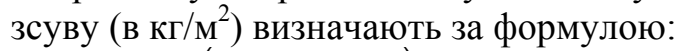

$$
\tau=\frac{\Delta \mathrm{G}\left(1-\mathrm{W}_{\text {бл }} \sqrt{2}\right)}{\Omega},
$$

де: $G$ - маса гирь на чаші за відрахуванням маси гирь, які пішли на переміщення пустого ящика, кг;

$\mathrm{W}_{\text {бл }}$ - коефіцієнт опору блока, при значному діаметрі блока (150-200 мм) та тонкому шнурі можна прийняти за 0. 
СТОРІНКА МОЛОДОГО ВЧЕНОГО

Фізико-механічні властивості інгредієнтів комбікормів (господарства Полтавськой області)

\begin{tabular}{|c|c|c|c|c|c|c|c|c|}
\hline \multirow[t]{2}{*}{ Тип та сорт зернових } & \multicolumn{2}{|c|}{$\begin{array}{c}\text { Щільність а.c.p., } \\
\Gamma / \mathrm{cm}^{3}\end{array}$} & \multicolumn{2}{|c|}{ Вага 1000 зерен, г } & \multicolumn{2}{|c|}{ Вологість, \% } & \multicolumn{2}{|c|}{ Об’ємна маса г/л } \\
\hline & значення & $\pm \mathrm{m}$ & Значення & $\pm \mathrm{m}$ & значення & $\pm \mathrm{m}$ & значення & $\pm \mathrm{m}$ \\
\hline 1 & 2 & 3 & 4 & 5 & 6 & 7 & 8 & 9 \\
\hline $\begin{array}{c}\text { Пшениця «Антоновка» } \\
\text { (КСП «Ковпакивец») }\end{array}$ & 1,350 & 0,005 & 37,890 & 0,259 & 11,800 & 0,158 & 729,000 & 1,155 \\
\hline $\begin{array}{c}\text { Пшениця «Срмак» } \\
\text { ТОВ «Октан» }\end{array}$ & 1,470 & 0,057 & 42,840 & 0,102 & 10,347 & 0,236 & 742,33 & 0,333 \\
\hline $\begin{array}{r}\text { Ячмінь «Мал } \\
\text { (КСП «Ковпаки }\end{array}$ & 1,250 & 0,014 & 0,444 & 0,256 & 12,340 & 0,120 & 577,33 & 1,153 \\
\hline $\begin{array}{c}\text { Ячмінь «Здобуток» } \\
\text { І рп }\end{array}$ & 1,345 & 0,064 & 45,240 & 0,102 & 8,600 & 0,065 & 623,667 & 0,333 \\
\hline $\begin{array}{c}\text { Кукурудза Хар.-295 } \\
\text { (СВК «Батьківщина») }\end{array}$ & 1,200 & 0,007 & 234,120 & 5,136 & 10,770 & 0,015 & 710,000 & 1,155 \\
\hline $\begin{array}{c}\text { Кукурудза «Тітан» } \\
(\text { КСП «Ковпакивец») }\end{array}$ & 1,430 & 0,206 & 273,780 & 0,068 & 15,550 & 0,134 & 705,33 & 0,333 \\
\hline $\begin{array}{c}\text { Горох «Мадонна» } \\
(\text { КСП «Ковпакивец») }\end{array}$ & 1,300 & 0,010 & 168,380 & 1,002 & 13,980 & 0,219 & 781,33 & 0,882 \\
\hline $\begin{array}{c}\text { Горох «Мадонна» } \\
(\text { СВК «Батьківщина») }\end{array}$ & 1,340 & 0,006 & 194,910 & 0,852 & 14,830 & 0,080 & 785,67 & 0,333 \\
\hline $\begin{array}{c}\text { Соя «Медея» } \\
\text { (Агрофірма «Маяк») }\end{array}$ & 1,100 & 0,026 & 134,320 & 0,577 & 9,040 & 0,152 & 720,000 & 0,577 \\
\hline $\begin{array}{c}\text { Соя «Романтика» } \\
\text { (СВК «Батьківщина») }\end{array}$ & 1,150 & 0,004 & 124,180 & 1,513 & 10,460 & 0,064 & 689,000 & 0,577 \\
\hline
\end{tabular}

Знаючи $\sigma$ та $\tau$, знаходять величину внутрішнього тертя $\operatorname{tg}_{\phi}$, сипучого матеріалу, який досліджують, в стані спокою.

$\operatorname{tg}_{\phi}=\tau / \sigma$, тобто $f_{M}$ сипучого матеріалу, який досліджують $=\tau / \sigma$.

Коефіцієнт тертя сипучого матеріалу об поверхню різних матеріалів (сталь, дерево, гумова стрічка та ін.) у спокої ( $\left.f_{0}\right)$ визначають так же, як і коефіцієнт внутрішнього тертя.

Різниця в визначенні коефіцієнтів внутрішнього тертя і коефіцієнтів тертя сипучих матеріалів по поверхні різних матеріалів полягає в тому, що в останньому випадку ящик із сипучим матеріалом, який досліджується, повинен рухатися по площині, виконаній із відповідного матеріалу.

Цю площину поміщають зверху лотка.

Величини граничних напружень $\sigma$ та $\tau$ визначають за формулами (1) i (2) з трьохкратним повторенням із різним числом вантажних пластин і при різній висоті шару сипучого матеріалу, який досліджується, в ящику.

Результати досліджень. Різна сировина та комбікорми володіють сипучістю, тобто здатністю ковзатися та скочуватися по похилій площи- ні. Показниками сипучості є кут природного ухилу та кут тертя різної сировини або комбікормів по поверхні матеріалу.

Кут природного ухилу - це кут між діаметром основи та утворюючої конуса, який виходить при вільному падінні маси зерна різної сировини або комбікормів на горизонтальну площину.

Кут тертя по поверхні - це найменший кут, при якому маса зерна, різної сировини або комбікормів починає самопливом рухатися по похилій площині.

На ступінь сипучості впливають форма, розмір, характер і стан поверхні зернової та дугової сировини i комбікормів, їх вологість, вміст i склад домішок, а також матеріал, форма та стан поверхні ковзання.

Найбільшою сипучістю і найменшим кутом природного ухилу володіють сировина та комбікорми шароподібної форми 3 гладенькою поверхнею.

При відхиленні шароподібної форми сипучість зменшується.

Легкі домішки значно знижують сипучість.

Підвищення вологості також зменшує сипучість й збільшує кут природного ухилу.

Дослідження показали, що при величині модуля помелу комбікорму 2,3 мм значення коефі- 
цієнта внутрішнього тертя - 0,51, а кута природного ухилу $-42^{0}$, а при величині модуля помелу комбікорму 1,76 мм, відповідно, 0,67 та $43^{0}$.

Значення абсолютно сухої речовини змінюються в певних межах залежно як від типу, так і від сорту зернових та зерно-бобових (див. табл.).

Так, зокрема для різних сортів пшениці а.с.p. знаходиться в межах $1,35-1,47$ г/ $\mathrm{cm}^{3}$.

У той же час а.c.p. для кукурудзи $-1,2-1,43$ г/ $\mathrm{cm}^{3}$,

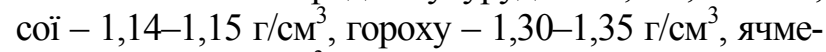
ню $-1,25-1,34$ г/ $\mathrm{cm}^{3}$.

\section{БІБЛІОГРАФІЯ}

1. Братерський Ф. Д., Пелевін А. Д. Оценка качества сырья и комбикормов / М.: Колос, 1983. C. $40-43$.

2. Норми технологічного проектування ВНТПАПК-11.07. Комбікормові підприємства. - К., 2007. $-37 \mathrm{c}$.

3. Правила організації і ведення технологічного процесу виробництва комбікормової продукції. К., 1998. -220 c.

4. Производство использования комбикормов / Шаршунов В. А., Червяков А. В., Бортник С. А. [и др.]. - Воронеж, 2005. - 289 с.

5. Піскун В. I. Розрахунок технологічної лінії ви-
Висновок. Проведені дослідження показали що значення абсолютно сухої речовини змінюються в певних межах залежно як від типу, так і від сорту зернових та зерно-бобових; зокрема для різних сортів пшениці а.c.p. знаходиться в

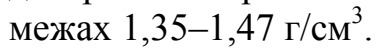

Значення величини коефіцієнта внутрішнього тертя та кута природного ухилу залежить від модуля помелу комбікорму і при модулі помелу комбікорму 2,3 мм значення коефіцієнта внутрішнього тертя $-0,51$, а кута природного ухилу $-42^{0}$.

робництва комбікормів 3 урахуванням абсолютно сухої речовини / Піскун В. І., Яценко Ю. В. // Вісник Харківського Національного технічного університету сільського господарства імені Петра Василенка. - Вип. № 108 / Сучасні проблеми вдосконалення технічних систем і технологій у тваринництві. - Х., 2011. - С. 25-31.

6. Техніка сільськогосподарська. Машини та обладнання для приготування кормів: Методи функціональних випробувань: ГСТУ 46.007 2000. - [Чинний від 2001.01.01]. - К.: Мінагрополітики України, 2000. - 73 с. (Галузевий стандарт України). 